as a teaching factor. That on kitchencraft, for example, merely illustrated the processes involved in making a pork pie. Most domestic science teachers, we think, would prefer their pupils to learn such a lesson by doing it themselves. But this is only the experimental stage, and though there is much to learn, a great deal of good work has already been done. To add to their value, the films are produced under authoritative direction. The films shown were made by Gaumont-British Instructional, Ltd., 12 D'Arblay Street, Oxford Street, W.1, who are to be congratulated on the excellent production, beautiful photography and useful running commentary. The whole performance will be presented later in provincial towns.

\section{Repton School Science Society}

ThE Repton School Science Society held its triennial conversazione in the Science School on June 22-23, when some fifty demonstrations and exhibits in biology, chemistry, and physics were shown by members of the Society. In the biology section a demonstration of the circulation of the blood in the tail of a tadpole was shown, both the pulse and the corpuscles being clearly visible. The laboratory aquarium and numerous specimens collected by the members were also shown. Two points of interest in the chemistry section were a demonstration of the spinning, bleaching, and 'souring' of rayon by a home-made model, and a set of experiments on testing the hardness of water and the various methods of water softening. Perhaps the most conspicuous feature of the physics section was a lecture on the electric spark, which included an elementary account of the mechanism of the spark, illustrated by various experiments on ionisation. The conversazione was well attended, and the visitors were impressed by the able manner in which the lectures and demonstrations were given.

\section{Architects' Unemployment Committee's Exhibition}

A N.ATIONAL crisis must naturally affect immediately those fields of activity most removed from the provision of essential necessities, and at the close of 1931 architects felt very severely the curtailment of their work due to restrictions required by economy. The Royal Institute of British Architects, in this emergency, set up a relief scheme in the form of payment for useful work of a public character made possible by subscriptions to a relief fund started by this and other kindred institutions. A sum of nearly $£ 12,000$ was collected, the whole of which has been expended in salaries and incidental costs in making surveys which should be of considerable value. The results are displayed on maps and models now on exhibition at 7, Bedford Square, London. Here on the 25-in. ordnance map may be seen indicated by colours the disposition of public, commercial and industrial buildings, business premises, and private and municipal housing over the whole of the London district and much of Kent. A 6-in. map shows London factories, shops, clubs, banks, and public buildings. A survey of the heights of London buildings has also been made and recorded. An interesting model of the London area is displayed showing the growth of London by centuries from Roman times to the present day. The information which can be grasped from the exhibition at a glance is most striking, and the maps should be of great value to Government and municipal departments. The display suffers from inadequate space, and though ingeniously arranged on curved surfaces, a comparison of the Hampton Court area on the walls with Greenford on the ceiling at some distance is not easy. The exhibition was opened by Lord Snell on June 22.

\section{Leadership in Industry}

IN the Mather Lecture of the Textile Institute delivered on May 25, Mr. A. P. Young (J. Text. Inst., May) gives a stimulating discussion of the functions and opportunities of industrial leadership. Reviewing the origin of the scientific era and the imperative necessity for adequate leadership in this age of power production, he sees in it the opportunity for many of the inspired qualities and the spirit of adventure which have animated previous pioneers of creative thought. Such leadership should be capable of harnessing to the task of industrial evolution, world co-operation and reconstruction the increasing productivity of the human unit, the accelerated rate at which raw materials are brought into service, the development of the electrical power era, the diminution of the time lag between discovery and industrial application, the linking of production and distribution. This must be done on a basis of planned co-operation, and leadership will function largely through its ability to stimulate the essential spirit of team work.

Mr. Young discusses the qualities required in the industrial leader of this calibre, among which he lists this ability to foster team work, creative imagination, intellectual sincerity and moral courage, power to co-operate with others, knowledge of administrative principles, capacity for delegating authority and scientific and technical knowledge. He emphasises the importance of a science as well as an art of management, and asserts that education for management is one of our greatest national needs, the need extending to the training of foremen and supervisors as well as managers and leaders carrying high responsibilities. Mr. Young discusses in some detail the problems of planning and leadership in the textile industry, laying stress on the service motive in industry. He sees a great future for the textile industry when planned and led along such lines, and concludes with a plea for co-ordination of the activity of the five research associations which now exist and for a five-fold expansion of the industry's expenditure on research within the next five years.

\section{A Photographic Centenary}

ON June 23, a gathering took place at Laycock Abbey, Wiltshire, to do honour to Henry Fox Talbot, who in 1834 in that house first succeeded in producing photographic impressions on paper. Fox Talbot, who was born in 1800 and died in 1877 , graduated at Cambridge in 1821, and became known 
for his original papers on mathematics, physics and astronomy. In 1831 he was elected a fellow of the Royal Society and two years later became M.P. for Chippenham. His experiments of 1834 were the outcome of an idea which had occurred to him when sketching the scenery of Lake Como with the aid of Wollaston's camera lucida, and they resulted in the development of Talbot's first process, photogenic drawing, described to the Royal Institution by Faraday in January 1839. The guests at Laycock Abbey on June $\mathbf{2 3}$ were received by Miss M. T. Talbot, the inventor's granddaughter, and an address on Fox Talbot's personality was given by his grandson, Prebendary W. G. Clark-Maxwell. Other addresses were given by Mr. H. Lambert, of Bath, and Mr. A. J. Bull, president of the Royal Photographic Society. A large exhibition of Fox Talbot's early apparatus and of his negatives and prints was arranged in the gallery and among these was probably the earliest existing photograph, a window in Laycock Abbey.

\section{Blériot's Flight Across the English Channel}

To commemorate the first flight by aeroplane across the English Channel by M. Louis Blériot on July 25, 1909, twenty-five years ago, a demonstration took place at his aerodrome at Buc near Paris on June 23, which was attended by the President of the French Republic, M. Lebrun, Lord Londonderry and Sir George Clerk, the British Ambassador. The old Anzani-engined monoplane in which the flight was made was on exhibition, and in the fly-past which closed the meeting, modern French aircraft scattered flowers upon it. At the time of the flight, M. Blériot was suffering from injuries to his foot and the crutches which he was using were strapped inside the fuselage. During the afternoon, many displays took part in which a squadron of Hawker Fury fighters of the Royal Air Force joined, and in a speech Lord Londonderry said that $M$. Blériot found a new high road of the air, which, within the short period of six years from the first flight, was to be traversed, not by a single Englishman paying a return visit to the coast of France, but by British pilots in their thousands, flying to the help and defence of Louis Blériot's fellow countrymen.

\section{Recent Acquisitions at the Natural History Museum}

AN important donation to the Zoological Department of the British Museum (Natural History) is a gift from the Rowland Ward Trustees of a mounted head of a female addax (Addax nasomaculatus) from the Sudan. An abnormal elephant tusk from Uganda has been presented by Mr. George Howard, of the Queen's Bays. This tusk is of interest as showing an early stage in the formation of the so-called 'fourtusked elephant'. Another donation of interest is that of three skulls of the so-called dwarf elephant from the Gola Forest in Sierra Leone, the gift of Sir Arnold Hodson, the Governor of Sierra Leone. These specimens would seem to substantiate the theory that this animal, known locally as the 'Sumbi', is merely the young phase of what has been termed the 'forest' elephant, which may be known by the name Elephas africanus cyclotis. There has been presented to the Department of Geology a large and valuable collection of type and figured specimens of rhinoceroses from the lower Tertiary beds of Baluchistan, described and figured by the donor, Mr. C. Forster Cooper; a large collection of fossil invertebrates from the United States, collected and presented by Miss Mary S. Johnston, and type specimens of three fossil fishes described by Prof. H. H. Swinnerton, and presented by him. An interesting collection of 727 pebbles, illustrating forms, origins, and materials, has been presented to the Department of Minerals by Mr. E. J. Dunnof Melbourne, who commenced collecting so long ago as 1856 .

Mr. J. E. Cooper has presented his herbarium to the Department of Botany of the Museum. It contains about 2,000 sheets of well-preserved flowering plants, a large number of which are aliens. The other specimens are chiefly from the London district, including parts now built over. A collection of more than 700 plants has been made by Mr. J. E. Dandy, assistant-keeper in the Department, who accompanied an expedition to the Anglo-Egyptian Sudan organised by Mr. C. G. T. Morison to study soilvegetation relations in an area where there is a big variation in rainfall. The area west of the Nile shows a large range between the dry north and the NileCongo divide in the south. Collections were made in many areas which were previously little known, and it is probable that much of interest from the point of view of geographical distribution will result, particularly from that from the high massif of Jebel Marra.

\section{Fire Protection of Electric Generating Stations}

IN the Electrician of June 22 there is an interesting account of the method adopted for protecting the large power station of the Bristol Corporation at Portishead from fire, by means of carbon dioxide. The great advantage of carbon dioxide for powerhouse use is that it extinguishes the fire with little risk of interrupting the operation of the station. The maintenance of a continuous supply of electric power is of the greatest importance in generating stations. The installation consists of carbon dioxide cylinder batteries centralised in a special building situated about 80 feet away from the station. Main pipes connect the cylinders with control valves placed at convenient points for directing the gas in the event of fire. Entirely automatic operation is arranged only for the transformer compartments, where thermostats are filled which operate the control valve. The quantity of gas stored is such that any section protected by the system can be flooded with gas more than sufficient to extinguish any fire. The drawbacks to using chemicals having a water content in rooms containing live electric wires are well known. In the event of fire arising in an alternator, there is an initial discharge of gas from ten cylinders. As the rotor continues to revolve for about half an hour before it comes to rest, the initial discharge is liable to be dispersed and so the gas concentration might 